\title{
Taking a risk with the detailed language of science
}

Anthill: A Novel

E.O. Wilson

W.W. Norton \& Company; 2010.

$A$ nthill by E.O. Wilson starts as a novel should: when and who are followed swiftly by where and how. "Two weeks before Labor Day, Raphael Semmes Cody sat with his cousin Junior in Roxie's Ice Cream Palace." A fine beginning, and by the end of the first page, you learn that the ice cream palace is in Clayville, Alabama, and to beat the heat the boys are going to set off down the Chicobee River in search of a giant snake. The fellow they meet on their little trip, Frogman, plays an essential role in the novel's climax. A solid opening, a good set up.

If you put down the story of Raff long enough to look up the author, it might surprise you to learn that E.O. Wilson is a renowned Harvard biologist. He has won two Pulitzer Prizes, one for a book on humanism and science, On Human Nature (1975) and the other for coauthoring The Ants (1990). This leads one to wonder why a successful sociobiologist and entomologist would try his hand at a novel.

Narrated by a family friend and Raff's mentor, Professor Frederick Norville, the story follows Raff from his boyhood summers exploring the Nokobee tract, an old-growth tract of longleaf pine savannah behind Lake Nokobee, to his adulthood. By the age of 12, he is doing a species map of the tract and neighbouring forest. There are startling passages of description along the way, from the "elegant tawny and black-headed" coachwhip snake to the depiction of Raff's girlfriend as a specimen with "a keen, intelligent face and two of the traits scientifically considered beautiful, small chin and wide-spaced eyes, but not the third, high cheekbones."

Despite a professed liking for Raff, the narrator fails to establish an emotional depth to the character. Indeed in chapter 11, the narrator abandons Raff and his family for an ecological history

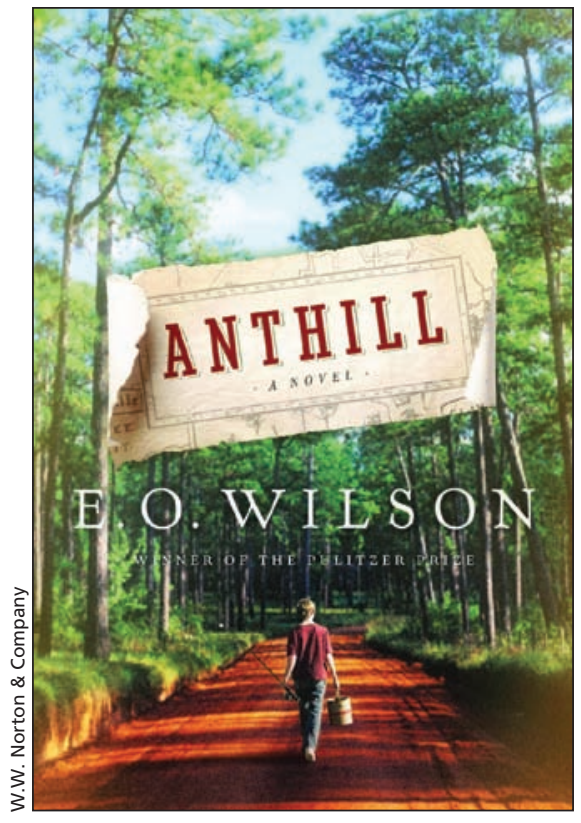

of the tract. In the following chapter about Raff's early explorations, the narrator distances the reader with lines such as "Nature works, Raphael learned, because it has order, and from order, it has beauty." So much for turning over rocks to discover grubs. In a chapter about Raff's encounter with a poisonous snake, the incident wraps up calmly, philosophically, "In time [Raff] understood that nature was not something outside the human world. The reverse is true. Nature is the real world, and humanity exists on islands within it."

Halfway into the book, 72 pages of narrative make up The Anthill Chronicles, which is Raff's thesis. It refers to an ant colony as a super-organism because the ants work together for the same cause, directed by the queen at the centre via pheromes. This idea of an ant colony working together as one organism is not new. In The Soul of the White Ant (1937), ${ }^{1}$ Eugène Marais argued that termites worked together as one organism similar to the human: each termitary has a brain, stomach, sexual organs, and each organ is in constant activity to a separate purpose, but like the human body "on closer observation we find that all the organs are really working for a communal purpose." Marais's comparison of ant to human as a single organism is to evoke our sympathy for the termites (his account of road-building ants meeting a straw bridge over water is a marvel of intimacy and fondness), whereas Wilson is furthering our understanding of our ecosystem while giving a warning.

A genetic mutation in a super-colony of ants causes them to over breed and over consume, leading to its own end. In case we don't see it, Wilson tells us in the prologue, "ants are a metaphor for us, and we for them." Humans are the supercolony consuming its way to extinction. Yet Wilson also holds out hope, if we can take inspiration from Raff.

Raff is a worker ant who gives his all to the cause of the greater good. His youth is given over to the study of the Nokobee tract and preparation for his role as its defender. As an adult he puts his life in danger for its protection. He aspires to create a model by which big business cooperates with ecological conservation - that the two may work together rather than in opposition, to their mutual benefit. Do the parts of the book work together as a novel? Yes. There may be clunkers in style (excessive passive voice, stale idioms) and the anthill narrative may not be to everyone's taste, but if you are willing to read of a young man as if he were an ant, whose very human desires are described through a distancing narrator who speaks the detailed language of science, then you will find yourself turning pages to find out how it ends. Wilson has taken a risk, combining the experimental with the traditional, ants and humans, ecology and business, life and death, and his risk does result in a fascinating novel. If this novel reaches someone who wouldn't pick up a book on biology, then all the better.

\section{Debra Martens MA \\ Writer \\ Ottawa, Ont.}

\section{Reference}

1. Marais E. The soul of the white ant. 4th ed. [translated from Afrikaans by Winifred de Kok.] London (UK): Methuen \& Co.; 1939.

CMAJ 2011. DOI:10.1503/cmaj.101749 